\title{
Hemşirelikte Kariyer Sorunları : Bir Ölçek Geliştirme Çalışması (Nursing Career Problems : Scale Development And Validation)
}

\author{
Doğancan ÇAVMAK (iD a, Emine ATALAY (iD b Sait SÖYLER iD b \\ aTarsus Üniversitesi, Sağlık Hizmetleri MYO, Sağlık Kurumları İşletmeciliği Programı, Mersin, Türkiye. dogancavmak@tarsus.edu.tr \\ bTarsus Üniversitesi, Sağlık Hizmetleri MYO, Sağlık Kurumları İşletmeciliği Programı, Mersin, Türkiye. emineatalay@tarsus.edu.tr \\ cTarsus Üniversitesi, Sağlık Hizmetleri MYO, Sağlık Kurumları İşletmeciliği Programı, Mersin, Türkiye. saitsoyler@tarsus.edu.tr
}

\begin{tabular}{|c|c|}
\hline MAKALE BİLGİSİ & ÖZET \\
\hline $\begin{array}{l}\text { Anahtar Kelimeler: } \\
\text { Hemşirelik } \\
\text { Sağlık Hizmetleri } \\
\text { Kariyer Sorunları } \\
\text { Ölçek Geliştirme }\end{array}$ & $\begin{array}{l}\text { Amaç - Hemşireler sağlık hizmetlerinin en önemli aktörleri arasında yer almaktadır. Hasta } \\
\text { bakım süreçlerinde etkinliğin sağlanmasında hemşirelerin rolü oldukça geniştir. Dolayısıyla iş̧ } \\
\text { aile yaşantısı uyumlu ve iş yaşamında motive olmuş hemşireler, hasta bakımının kalitesinde } \\
\text { önemli belirleyicilerdir. Hemşirelerin iş yaşam kalitelerinin iyileştirilebilmesi için doğru ölçüm } \\
\text { araçları ile kariyer sorunlarının tespit edilmesi gerekmektedir. Bu çalışmanın amacı, oldukça } \\
\text { geniş boyutlardan oluşan kariyer sorunlarının tespit edilebilmesi için, kapsayıcı bir ölçüm aracı } \\
\text { geliştirmektir. }\end{array}$ \\
\hline $\begin{array}{l}\text { Gönderilme Tarihi } 28 \text { Haziran } \\
2019 \\
\text { Revizyon Tarihi } 28 \text { Ağustos } 2019\end{array}$ & $\begin{array}{l}\text { Yöntem - Çalışma } 208 \text { hemşire ile gerçekleştirilmiştir. Tasarlanan } 31 \text { önermeli taslak ölçeğe dair } \\
\text { kapsam geçerliliği, yapı geçerliliği ve güvenirlilik testleri gerçekleştirilmiştir. Analizler SPSS } \\
22.0 \text { ve LISREL } 8.8 \text { paket programları ile yapılmıştır. }\end{array}$ \\
\hline $\begin{array}{l}\text { Makale Kategorisi: } \\
\text { Araştırma Makalesi }\end{array}$ & $\begin{array}{l}\text { Bulgular - Analizler sonucunda, ölçek } 4 \text { boyutlu ve } 23 \text { önermeli bir yapiya kavuşmuştur. Tüm } \\
\text { önermelerin faktör yükleri } 0.40^{\prime} \text { dan yüksek ve t değerleri } 1.96 \text { 'dan yüksek bulunmuştur. Uyum } \\
\text { indekslerinin beklenen değerler arasında olduğu görülmüştür. Cronbach alpha değeri } 0,893 \\
\text { olarak hesaplanmıştır. Test ve tekrar test sonuçları arasında istatistiksel olarak yüksek düzeyde } \\
\text { bir ilişki olduğu görülmüştür. }\end{array}$ \\
\hline & $\begin{array}{l}\text { Tartışma - Ölçeğin, hemşirelerin kariyer sorunlarını, farklı boyutları ile ölçmek üzere, yapı } \\
\text { olarak uygun olduğu, zamana göre geçerli olduğu ve güvenilir olduğu tespit edilmiştir. }\end{array}$ \\
\hline ARTICLE INFO & ABSTRACT \\
\hline $\begin{array}{l}\text { Keywords: } \\
\text { Nursing } \\
\text { Healthcare Services } \\
\text { Career Problems } \\
\text { Scale Development }\end{array}$ & $\begin{array}{l}\text { Purpose - Nurses are one of the most important groups in healthcare. The role of nurses in } \\
\text { providing effective patient care is very wide. Therefore, nurses who are compatible and } \\
\text { motivated in work life are important determinants of quality and success of care. It is necessary } \\
\text { to measure career problems via the right measurement tools in order to improve the } \\
\text { nurses'quality of worlk life. This study aims to develop a inclusive measurement tools which } \\
\text { include vary dimension of career problems. }\end{array}$ \\
\hline Received 28 June 2019 & $\begin{array}{l}\text { Design/ Methodlogy/Approach - The study was conducted with } 208 \text { nurses. Content validity, } \\
\text { construct validity and reliability analysis was conducted using SPSS } 20.0 \text { and LISREL } 8.8 \text {. }\end{array}$ \\
\hline $\begin{array}{l}\text { Revised } 28 \text { Auğust } 2019 \\
\text { Accepted } 5 \text { September } 2019\end{array}$ & $\begin{array}{l}\text { Findings - The scale has } 4 \text { factors and } 23 \text { statements according to content and construct validty } \\
\text { tests. Each stataments have factors' weights higher than } 0.40 \text { and t-values are higher than } 1.96 \text {. } \\
\text { It was observed that fit indices were among the acceptable range. Cronbach alpha coeffeccinent } \\
\text { of the scale is } 0.893 \text {. There is significant correlation between the test-retest results. }\end{array}$ \\
\hline Research Article & $\begin{array}{l}\text { Discussion - It was seen that, the scale was suitable as structure and content and reliable for } \\
\text { measuring the nurses' career problems by vary dimensions. }\end{array}$ \\
\hline
\end{tabular}

\section{GİRIŞ}

Sağlık hizmetleri oldukça karmaşık ve özellikli hizmetlerdir. Çok fazla sayıda ve farklı yetkinliklerde insan kaynağı hizmet süreçlerinde yer almaktadır. İnsan hayatına temas eden sağlık hizmetleri, uzun süreler ve vardiyalı çalışmayı, yüksek psikolojik ve fiziksel dayanıklılı̆̆ı, güçlü bir iletişimi ve işbirliğini gerektirmektedir. Bu gibi faktörler, sağlık insan kaynağını büyük oranda diğer üretim alanlarındaki insan kaynağından farklılaştırmaktadır. Sağlık hizmet sunumunun oldukça önemli bir noktasında yer alan hemşireler, tüm bu faktörlere oldukça yoğun bir şekilde maruz kalmaktadır. Dolayısı ile hemşirelerin iş yaşamları, motivasyon düzeyleri ve bağlılıkları her daim geliştirilmek için incelenmelidir. Gelişim ve ilerleme 


\section{D. Çavmak - E. Atalay - S. Söyler 11/3 (2019) 1897-1910}

ancak doğru ihtiyaç tespiti ve ölçüm ile sağlanabilmektedir. Dolayısı ile insan kaynağının çalışma yaşamını geliştirmek adın, yaşanılan kariyer sorunları doğru bir şekilde ölçmek oldukça önemli bir husustur.

Kariyer sorunları oldukça geniş boyutlar çerçevesinde değerlendirilmektedir. Cam tavan, çift kariyerlilik, ay 1şığı sorunu, iş aile çatışması, mobbing, tükenmişlik, kariyer şoku vb. gibi birçok alt boyut kariyer sorunları çerçevesinde değerlendirilmektedir. Esasen her bir kariyer sorunu için ayrı ölçüm araçları da geliştirilmiş ve güncellenmeye devam edilmektedir. Örneğin tükenmişlik düzeyinin tespiti için Masclah'ın ölçeği (Maslach ve Jackson, 1981), mobbing için Leyman tarafından geliştirilen ölçekler kullanılabilmektedir. (Leyman, 1996) Bu boyutlar, tüm sektörler için genel bir çerçeve sunmasının yanı sıra, iş alanlarına göre boyutlara atfedilen nedensellik düzeyi farklılaşabilmektedir. Çalışmamızın da temelini oluşturan hastane hemşireleri ile ilgili Google Akademik veri tabanında tarama yapıldığında, çoğunlukla iş stresi, tükenmişlik ve mobbing konularının ön plana çıktığı, kariyer sorunlarının genel olarak nadiren incelendiği görülebilmektedir. 2019 yılında hemşireler ile yapılmış olan tükenmişlik çalışmalarının önemli bir kısmında Masclach tükenmiş ölçeğinin kullanıldığı (Can ve Hisar, 2019; Özen ve Yüceler, 2019; Çalışkan ve Pekkan, 2019), duyarsızlaşma, duygusal tükenme ve düşük kişisel başarı hissi boyutlarının değerlendirildiği görülmüştür. Hemşirelerin, çalıştıkları kurumlardaki kariyer planlamalarına yönelik algılarının (Bektemur vd., 2016), yeni işe başlayan hemşirelerin sorunlarının (Öztürk vd., 2016) irdelendiği çalışmaların da olduğu göze çarpmıştır.

Bu bağlamda, bu çalışmada, sağlık hizmetleri için oldukça önemli ve kritik bir noktada yer alan hemşirelerin, kariyer sorunlarını doğru bir şekilde belirleyebilmek için, kapsayıcı ve tutarlı bir ölçüm aracı geliştirilmesi amaçlanmıştır. Geliştirilecek ölçüm aracının, kariyer sorunlarının tüm bahsedilen boyutlarını içermesi temel amaç olmuştur. Daha önce geçerlik ve güvenilirlikleri yapılmış olan ölçeklerin önermeleri amaç doğrultusunda kısmi olarak alınmış ve revize edilmiş, cam tavan, çift kariyerlilik, çift kariyerli eşler boyutları için literatür doğrultusunda ifade ettikleri sorunları karşılayabilecek önermeler geliştirilmiş ve analiz edilmiştir.

\section{KURAMSAL ÇERÇEVE}

21.yy.'de kurumların çalışan memnuniyetini sağlamaları hizmet kalitesi sebebiyle önem arz etmektedir. Tüm kurum ve kuruluşlarda önem gösterilen bu konu sağlık kurumlarında çalışmakta olan sağlık personelleri için de geçerlidir. Çalışanlara iyi bir kariyer fırsatı sunmak, kariyer gelişimlerine önem vermek hizmet kalitesi için önemliyken aynı zamanda kariyer sorunlarının belirlenmesi ve bunlara yönelik önlemlerin alınması da kurumlar için öncelik haline gelmektedir.

Tüm kurum ve kuruluşlarda önem taşıyan kariyer ile ilgili tanımlara bakılırsa şu durumlarla karşılaşılmaktadır:

Decenzo ve Robbins (2007:233), kariyeri bireyin hayatı boyunca işiyle ilgili edindiği deneyimler şeklinde tanımlarken; bir başka tanıma göre, bireyin ve kurumun hedefleriyle direkt bağlantılı ve bireyin hayatı boyunca yaşadığı ve yaşayacağı kısmen kendi kontrolünde olan iş tecrübesi ve çalışmalarıyla bağlantılı bir süreç şeklinde ifade edilmektedir (Aydemir, 1995:25). Gürbüz (2017:243), ise kariyer kelimesini bazen bir meslek bazen de bir işte yükselmek anlamında kullanılan; bireyin çalışma hayatı boyunca işle ilgili deneyimler dizisi şeklinde tanımlamıştır.

Kariyer, hem işgörenler hem de kurumlar açısında önem taşımaktadır. İşgörenlerin kendi güçlü ve zayıf yönlerinin belirlenmesi, kurum içerisinde ki iş fırsatlarıla ilgili bilgi edinmeleri, kariyer hedeflerinin belirlenmesi ve bu hedeflere ulaşacak eylem planlarının oluşturulmasına olanak sağlayan kariyer geliştirme uygulamaları, kurumların ilerleyen zamanlarda gereksinim duyacakları personeli önceden belirlemelerine olanak sağlayacaktır (Dündar, 2015:269).

Kariyer kavramı bireysel ve örgütsel olmak üzere 2 temel boyutta incelenebilir. Kariyer planlama bireysel boyutu, kariyer yönetimi örgütsel boyutu ifade etmektedir. İşletmelerde kariyer geliştirme sistemi başlı̆̆ altında ele alınan kariyer planlama ve kariyer yönetimi konularına bakılırsa;

Kariyer Planlama; bireyin kendi kendini değerlendirerek; bilgi, beceri, güçlü ve geliştirmesi gereken yönlerini ortaya koyarak, örgüt içinde ve dışında kariyer fırsatlarını belirleyerek bu doğrultuda kısa, orta ve uzun süreli hedeflerini belirleyip, planlarını hazırlaması ve bu planları uygulamasıyken; kariyer yönetimi, kurumların 


\section{D. Çavmak - E. Atalay - S. Söyler 11/3 (2019) 1897-1910}

ileride ihtiyaç duyacağı nitelikte personeli zaman içerisinde yetiştirmesine yönelik faaliyetlerdir (Dündar, 2015:270).

Personel kariyer planlaması ve kurumun kariyer yönetim politikası ile çeşitli sorunlar yaşamaktadır. Kariyere ilişkin sorunlara baktığımızda; cam tavan, çift kariyerli eşler, çift kariyerlilik, ay ışığı sorunu, kariyer evrelerinde ortaya çıkan sorunlar ve son dönemde kariyer sorunları içerisinde ele alınan iş- aile çatışması, iş stresi, mobbing ve tükenmiş konuları kısaca ele alınacaktır.

Cam Tavan: Cam tavan, kadın çalışanların üst düzey yönetim noktalarına gelmesini engelleyen örgütsel ve davranışsal önyargılardan meydana gelen görünmeyen yapay engellerin anlatımı için kullanılmaya başlanmış olup; sonrasında özellikle büyük ölçekli kurum ve kuruluşlarda kadınların belli bir düzeyden sonra bir sonraki düzeye geçmesine olanak vermeyen şeffaf engeller şeklinde tanımlanmaktadır (Wirth, 2001:45; Bombuwela ve Chamaru, 2013:6).

Kadınların üst yönetimlerde görevlendirilmemesi ile ilgili çeşitli gerekçeler öne sürülmüştür. Bu gerekçelere bakıldığında; (Budak 2008:277)

- Kadın personelin çocuğu büyütmek için belirli bir süre kariyerlerine ara vermeleri ya da tamamen durdurmaları,

- Kadın personelin iş- aile yaşamlarındaki sorumluluklarını dengeleme çabaları,

- Kadın personelin geleneksel olarak mühendislik ve işletmecilik becerilerinden yoksun olmaları,

- Başarılı kadınların kendi işlerini kurarak, bağımsız bir şekilde çalışma istekleridir

Cam tavan sendorumu ile ilgili yaygın olarak bilinen ölçek Payne (2005)'nin, “The Glass Ceiling Ten Years Later: A Study of the Professional Woman' s Perception of Success in Corporate America " adlı çalışmasında geliştirdiği ölçektir.

Çift Kariyerli Eşler: Son zamanlarda aile yapılarında meydana gelen değişimler ve rollerdeki farklılaşmanın etkisiyle ortaya çıkan çift kariyerli eşler kavramı, her iki eşin de kariyerli işlerde çalışmasıyla meydana gelen çalışma yaşamı ve etkileşimini konu almaktadır (Demirel, 2017:67). Acar (1994:21-29) yaptı̆̆ tanımda, çift kariyerli aileleri; beraber bir aile hayatı yaşamakla birlikte, her iki eşinde kendi kariyerlerini sürdürdüğü aileler şeklinde tanımlamıştır. Çift kariyerli eşler kavramı dendiğinde; her iki eşin çalışma yaşamı içerisinde olması ve eşleri kariyer hedeflerinin peşinden koşması anlaşılmaktadır. Bu tarz kariyerlere sahip çiftleri üç farklı gruba ayırmak mümkündür. Bunlar;

- Aynı işletmede çalışan ve aynı kariyeri izleyen çiftler,

- Aynı işletmede çalışan fakat farklı kariyer izleyen çiftler,

- Farklı işletmede benzer veya farklı kariyer izleyen çiftler olarak gruplandırılmaktadır (Flippo, 1984:262263).

Kavramın daha iyi anlaşılabilmesi için çalışma ve kariyer kavramlarının ayrımı önem arz etmektedir. Kadın aile bütçesine katkıda bulunmak için çalışıyorsa bu durumda çalışma; kendi bireysel hedeflerine yönelik çalışıyorsa bu durum kariyer şeklinde değerlendirilir (Karadoğan, 2009:137).

Çift Kariyerlilik: Çift kariyerlilik, bireyin farklı iki kariyer alanında ilerlemesi şeklinde tanımlanmıştır. Çift kariyerlilikten bahsetmek için; bireyin çalıştı̆̆ iki işte belirli bir uzmanlık ve deneyim gerektirmelidir. Bununla birlikte her iki işte bireye unvan ve kariyer sağlamalıdır. (Aytaç, 2005:276) Çift kariyerliliğin olumsuz tarafına bakıldığında, bireylerin enerjilerini tek bir alanda kullanmaları yerine aynı anda iki farklı kariyerde yükselmeye çalışmaları, enerjilerinin bölünmesine ve başarılarının düşmesine sebep olmasıdır (Şimşek ve Öge, 2014:290).

Ayışığı: Ayışığı kavramı ile literatürde yapılan tanımlara bakıldığında; Kimmel ve Conway (2001:89-120), bireylerin esas işlerinde tam zamanlı çalışma saatlerininin olmaması ve esas işten yeteri kadar para kazanamamaları durumunda esas işin yanında maddi ve manevi tatmin yaşamak için başvurdukları ikincil işleri ayışığı aktiviteleri olarak nitelendirilmiştir. Ayışığı, bireylerin kendi işlerine ek olarak, iki veya daha fazla işte çalışmasıdır. Düzenli bir işe sahip olan bireyin çoğunlukla gizli bir şekilde akşam saatlerinde ikinci bir işte çalışması neden bu soruna ay ışığı denildiğini ortaya koymaktadır. Günümüzde ek işler, günün farklı 


\section{D. Çavmak - E. Atalay - S. Söyler 11/3 (2019) 1897-1910}

saatlerinde yapılabildiği halde yine de ayışığı başlığı altında ele alınmaktadır (Kırmızıgül, 2017:170-171). Ayışığı sorunu düzenli bir şekilde çalışan bir bireyin mevcut çalışma saatlerinin dişında başka bir işte de çalışması durumunda karşımıza çıkan bir sorundur. Bireylerin ek bir işte çalışmalarının sebebi, kendi işlerini kaybetme riskine karşı yaptıkları ek işi bir garanti olarak görmeleri ve ek bir gelire sahip olmak istemeleridir (Okakın, 2008:147).

Kariyer Evrelerinde Ortaya Çıkan Sorunlar: Kariyerin başında karşımıza çıkan kariyer şoku; henüz gerçek iş hayatına atılmamış öğrenci ve iş arayan adayların karşılaştıkları bir sorundur. İşle ilgili yüksek beklenti ve hedefleri olan bu bireyler, çalışma ortamına girip çalışma yaşamının gerçek yüzüyle karşı karşıya kaldıklarında bir şok yaşamaktadırlar. Gerçeklik şoku olarak da bilinen bu karşılaşma kariyer şokudur (Gürbüz, 2017:316). Kariyerin orta evrelerinde, kişinin iş yaşamında belirli bir dönem kariyer ilerlemesinin durması durumu olan kariyer platosu karşımıza çıkmaktadır. Kariyerinin son evresinde ise uzun süre çalışmış olan bireylerin emeklilik ile ilgili düştükleri sıkıntılı durum karşımıza çıkmaktadır (Dündar, 2015:295).

İş Aile Çatışması: İş aile çatışması, bireylerin iş ve aile alanlarında meydan gelen rol taleplerinin birbirleriyle uyumsuz olması sonucu karşımıza çıkan çatışmadır (Greenhaus ve Beutell, 2016:77). İşle ilgili ve iş dışı rollerin vermiş olduğu yükümlülüklerin her zaman kusursuz bir şekilde ve düzen içerisinde yerine getirilmesi imkânsızdır. Aile ve iş yaşamında rollerin birbirleriyle uyumlu olmaması iki boyut arasında çatışmaların meydana gelmesine yol açmaktadır. Bireylerin rolleri gerektiği gibi yerine getirememesinde en önemli etken zamandır. Bireyler aile yaşamında ve işte yerine getirmesi gereken sorumlulukların farkında olmalarına rağmen gerekli yükümlülükleri gerçekleştirmek için yeterli zaman olmamasından dolayı çatışmalar yaşamaktadır. Bireylerin evde yaşadıkları stres sebebiyle işte yüksek performans gösterememesi ya da işte yaşadığı stresi eve taşıması sebebiyle iş-aile çatışması meydana gelmektedir (Kopelman, Greenhaus ve Connolly, 1983:198-200).

İş Stresi: fiziksel stres kaynaklarıyla baş edilememesini sonucu, fiziksel ve zihinsel bir hastalığa dönüşebilen, istenmeyen bir olgu olarak ifade edilmektedir (Özdevecioğlu, 2003:114). İşs stresi, işle ilgili etmenlerin sonucunda bireyi normal fonksiyonlarından saptırarak, fiziksel ve psikolojik davranışlarını değiştiren bir durumdur (Cam, 2004). İş hayatı bireylerin yaşamında önemli bir yer kaplamaktadır. Çalışma hayatında kendisini iyi hisseden birey, aile ve sosyal yaşamda da eş yönlü bir mutluluk yaşayacaktır. İş yaşamında meydana gelen baskılar bireyin kendini yetersiz hissetmesine sebep olarak bireyi strese sokacaktır (Baltaş ve Baltaş, 2008:90).

Tükenmişlik: Fiziksel ve zihinsel yorgunlukla birlikte yaşanan duygusal tükenme durumu şeklinde ifade edilmektedir (Shirom, 1989:25-48). Maslach ve Jackson (1981:99-113), tükenmişliği insan ilişkilerinin oldukça yoğun olduğu işlerde çalışan bireylerde duygusal tükenmeyle birlikte sinizmin ortaya çıktığı bir sendrom olarak tanımlamışlardır. Tükenmişlik insan ruhunu erozyona uğratan, kişinin kendini kronik bir şekilde yorgun ve bitkin hissetmesine sebep olan, kişiyi sinikleştiren, kişinin işinden ve diğer insanlardan uzaklaştıran tutum ve davranışlar sergilemesine yol açmaktadır (Maslach, Leiter, 1997:23). Tükenmişliğe ilişkin birçok araştırmacı tarafından farklı boyutlar ortaya konmuş olsa da literatürde en çok kabul gören Maslach ve Jackson'ın öne sürmüş olduğu boyutlardır. Maslach tükenmişliği 3 boyutta değerlendirmiştir; bunlar, duygusal tükenme, duyarsızlaşma, düşük kişisel başarı hissidir (Maslach ve Jackson, 1981:98-113). Duygusal tükenme tükenmişliğin bireysel boyutu ve tükenmişlik yaşandığına ilişkin en önemli göstergedir. Duyarsızlaşma, tükenmişliğin kişlerarası boyutu olup; bireyin çevresindeki olay ve kişilere karşı mesafeli bir tutum alma halidir. Son olarak düşük kişisel başarı hissi, bireyin kensine ilişkin boyutu olup; kendisini yetersiz, başarısız hissetmesidir (Seçkin, 2017:231).

Mobbing: Bireye, işyerinde işverenlerce veya iş arkadaşları tarafından tekrarlanan bir şekilde uygulanan bir çeşit psikolojik terör olarak ifade edilen kavram; çalışanlara üstleri, astları veya aynı düzeydeki iş arkadaşları tarafından sistematik bir biçimde uygulanan her türlü şiddet, kötü muamele, aşağılama, tehdit, taciz gibi davranışlardır. Bir davranışın mobbing olarak sayılması için davranışın, en az haftada bir kere genelinde ise 6 ay gibi bir süreye yayılması ve hatta bu süreyi geçmesi gerekmektedir (Leyman, 1996: 168). Mobbingle ilgili çalışmalarıyla ve ilgili literatürde geliştirdiği ölçeğiyle en çok anılan isim olan Leymann'ın LIPT anketinde 45 ifadeden oluşan mobbing davranışları 5 faktör halinde ele alınmıştır. Bunlar; sosyal ilişkilere saldırılar, iletişime yönelik saldırılar, sosyal konuma saldırılar, sağlığa yönelik saldırılar, mesleki ve özel yaşama yönelik saldirılardır (Tinaz, 2008:52). 


\section{D. Çavmak - E. Atalay - S. Söyler 11/3 (2019) 1897-1910}

Literatürde hemşirelerin yaşamış olduğu sorunlara ilişkin çalışmalara bakıldığında; tükenmişlik üzerine ilk yapılan çalışmalar sağlık sektöründe sağlık çalışanlarında görülen yorgunluk hissi, işten ayrılma niyeti, hayal kırıklığı gibi durumları tanımlamak için ortaya atılmış ve sağlık çalışanlarında tükenmişliğin büyük bir risk taşıdığı çalışma sonrasında ortaya konmuştur. Karaca (2019), hemşirelerin kariyer hayatı boyunca karşılaştıkları engelleri 6 ana tema üzerinde belirlemiştir. Bunlar, bireysel, ailesel, örgütsel, çevresel, siyasal, toplumsal sorunlardır. Marangoz (2019)'un hemşireler üzerinde yaptığ1 çalışmasında hemşirelerin hem işyerinde hem de işyeri dışında toplumsal cinsiyete dayalı ayrımcılığın sebep olduğu eksiklikleri tespit etmiştir. Ürdün'de özel sektörde çalışan hemşireler üzerinde yapılan bir çalışmada, yaşanan sorunların, tatminsizlik, tükenmişlik, yüksek devir oranları boyutlarında yoğunlaştı̆̆ı görülmüştür (Mrayyan, 2006:8586). Uluslararası Çalışma Örgütü'nün (ILO) hemşirelikte stres kaynakları üzerine hazırladığı bir raporda; kişinin yetenekleri ile işin gerektirdiği niteliklerin uyuşmaması ve kişinin beklentileri ile işten algılanan değerin uyuşmaması(kariyer şoku), iş üzerindeki kontrol düzeyinin düşük olması, düşük destek algısı, iş yükü, iletişim eksikliği boyutları ön plana çıkarılmıştır (Cox vd., 1996: 4). Ergüney ve arkadaşlarının (2001) yaptığı çalışmada da hemşirelerin maruz kaldığı mesleki risklerin hemşireler üzerinde stres yarattığını belirlemişlerdir. Bu mesleki risklerin, kariyer sorunlarından tükenmişlikle bağlantılı oldukları görülmektedir. Yine hemşirelerin stres düzeylerini inceleyen bir çalışmada, Akbal ve arkadaşları (2001), işe özgü stres, kariyer gelişiminden kaynaklana stres, örgütsel yapı kaynaklı stres gibi boyutlar içeren Örgütsel Stres Kaynağı ölçeğini kullanmışlardır. Öztürk ve arkadaşlarının (2016), hemşireler üzerinde yaptığı çalışmada, meslek hayatına yeni başlayan hemşirelerin ücretlendirme, hastalar ve hekimlerle ilgili birçok sorun yaşadığ gözlenmiştir. Yıldırımalp ve arkadaşlarının (2014) hemşireler üzerinde yaptıkları çalışma da; yaş ilerledikçe hemşirelerin iş- aile çatışması yaşadığını ortaya koymuştur. Bunların yanı sıra; Çatak (2005), Karahan ve Bener (2005), Yüksel (2005), Karahan vd. (2007), Şirin (2008), Mutlu (2010), Karakuş (2011), Koç, Bardak ve Yılmaz (2014), Bektemur vd. (2016), Öztürk vd. (2016) çalışmaları incelenmiştir. Stres ve tükenmişlik özelinde yoğunlaşan boyutların ötesini de kapsamak amacıyla, ölçek hazırlama çalışması yapılırken kariyer sorunları olarak; cam tavan, çift kariyerlilik, iş- aile çatışması, iş stresi, mobbing, tükenmişlik başlıkları ön plana çıkarılmıştır.

\section{YÖNTEM}

\subsection{Gerekçe ve Amaç}

Sağlık hizmetleri, yaşanan teknolojik gelişmelere rağmen insan faktörünün büyük bir rol oynadığ1 emek yoğun bir sektör olma özelliğini sürdürmektedir. Hemşireler hizmet sunumu süreçlerinde aktif olarak rol alan, hekimler ile beraber hastalarla en yoğun şekilde ilişki içerisinde bulunan, hata yapmanın çok ağır sonuçlar doğurabileceği bir ortamda çalışmaktadırlar. Burada hemşirelerin iş yoğunluğu ve zaman baskısıyla beraber motivasyonlarının düşmesi, yorgunluklarının bir süre sonra tükenmişlik düzeyine erişmesi, yönetici ve iş arkadaşları ile yaşadıkları sorunlar gibi iş kaynaklı zorlukların yanı sıra aile yaşamları ile ilgili zorluklarla karşı karşıya kalmaları da mümkündür. Ayrıca hemşirelerin çoğunlukla kadın çalışanlardan oluşması neticesinde bu gruba özgü yaşanabilecek başka bir takım zorluklar da vardır. Bu bağlamda hemşireler sağlık çalışanları içerisinde özel olarak irdelenmesi gereken bir grup olma özelliği göstermektedirler. Bu özellikleri itibarı ile hemşirelerin kariyerlerinde hem genel hem de mesleklerine özgü bir takım problemler yaşamaları olası olmaktadır. Bu doğrultuda bu çalışmanın amacı hemşirelerin karşılaştıkları/karşılaşabilecekleri kariyer sorunlarının ölçülmesi ve değerlendirilmesine yönelik olarak hemşirelerin kariyer sorunları ölçeğinin geliştirilmesi amaçlanmıştır.

\section{2. Örneklem}

Araştırmada örneklem olarak ölçekte yer alan 31 maddenin en az 5 katı kadar (155) katılımcıya ulaşılması hedeflenmiştir. Bu kapsamda, 31 maddelik taslak ölçek, online formatta düzelenmiş ve özel hastanelerde aktif olarak çalışmakta olan hemşirelere gönderilmiştir. Anketlerin uygun şekilde cevaplanmayabileceği düşünülerek online ölçek toplamda 220 hemşireye gönderilmiş, tam ve eksiksiz olarak doldurulan 208 anket ile analizler gerçekleştirilmiştir. Araştırmada ayrıca test ve tekrar test analinin gerçekleştirilebilmesi için 50 katılımcıya 3 hafta arayla iki defa uygulama yapılmıştır.

\subsection{Yöntem}




\section{D. Çavmak - E. Atalay - S. Söyler 11/3 (2019) 1897-1910}

Araştırma bir ölçek geliştirme çalışmasıdır. Çalışmada öncelikle ilgili literatür araştırmacılar tarafından derinlemesine incelenmiş ve bu alanda gerçekleştirilen çalışmalar analiz edilmiştir. Bu bağlamda incelenen ölçeklere bakıldığında; Leymann'ın 45 ifadeden oluşan Mobbing ölçeği; Karaca (2007) tarafından geliştirilen Cam Tavan Sendromu Ölçeği; Payne (2005)'nin, "The Glass Ceiling Ten Years Later: A Study of the Professional Woman' s Perception of Success in Corporate America " adlı çalışmasından uyarlayarak Türkçeye çeviren Özünlü (2013)'nün araştırmasında kullandığı "Cam Tavan Sendromu Ölçeği"; Smith ve arkadaşlarının (2012) geliştirdiği, "Kariyer Yolları Ölçeği”; Maslach ve Jackson (1981) tarafından geliştirilmiş; Ergin (1992) tarafından Türkçe'ye uyarlanan, Maslach Tükenmişlik Ölçeği, Schaufeli ve Salanova (2007) tarafından geliştirilen Maslach Tükenmişlik Envanteri Genel Araştırması'ndan uyarlanmış olan Tükenmişlik ölçeği; Netenmeyer, Boles ve McMurrian (1996) tarafından geliştirilen İş-Aile Çatışması ölçeği; House ve Rizzo (1972) tarafından geliştirilen İş Stresi ölçeği, Acar ve Zuhal Batlaş (2006) tarafından geliştirilen İş Stresi ölçeği; Diener, Emmons, Larsen ve Griffin (1985) tarafından geliştirilen; Köker (1991) ve Yetim (1991) tarafından Türkçeye uyarlanan, Yaşam Doyumu Ölçeği; Aytaç ve arkadaşları tarafından (2001) geliştirilen Çift Kariyerli Eşlere Yönelik Tutum ölçeğidir. Bu ölçek maddeleri ve bununla beraber literatürde sıklıkla bahsedilen kariyer sorunları irdelenmiş ve uzman görüşleri doğrultusunda bir madde havuzu oluşturulmuştur Bu havuz içerisinden sağlık hizmetleri çalışanlarının kariyer sorunlarını belirleyeceği düşünülen maddeler güncel haliyle ölçekte yerini almıştır. Ölçeği oluşturan önermeler 7'li Likert skalasında değerlendirilmiştir. (1=Kesinlikle katılmıyorum, 7=Kesinlikle katılıyorum). Ölçekten alınan puanların artması hemşirelerin ilgili boyutu bir kariyer sorunu olarak algıladığını/deneyimlediğini ifade etmektedir.

Ölçeğin güvenilirliği(iç tutarlılığı) Cronbach's Alpha katsayısı hesaplanarak incelenmiş, zamana göre kararlılığı ise test-tekrar test korelasyonu ile tespit edilmiştir. Ölçeğin yapı geçerliliğinin incelenmesinde açımlayıcı faktör analizinden yararlanılmıştır. Son olarak ölçeğe ilişkin doğrulayıcı faktör analizi gerçekleştirilerek çalışma sonlandırılmıştır. Araştırmada verilerin analizi SPSS 22.0 ve LISREL 8.80 paket programları ile gerçekleştirilmiştir.

\section{BULGULAR}

Araştırmada öncelikle katılımcılara ilişkin tanımlayıcı istatistiklere yer verilmiştir. Tanımlayıcı istatistikler tablo 1'de özetlenmiştir. Buna göre araştırmaya katılanların \%83,7'si kadın, \%61,5'i çocuk sahibi ve \%70,2'si 5 yıldan fazla mesleki deneyim sahibidir. Katılımcıların yaş ortalaması ise 35,52 $\pm 9,04^{\prime}$ tür.

Tablo 1. Demografik Veriler

\begin{tabular}{rlrrr}
\hline \multicolumn{2}{c}{ DEĞIŞKEN } & & $\mathrm{n}$ & $\%$ \\
\hline \multirow{2}{*}{ Cinsiyet } & Kadın & 174 & 83,7 \\
& Erkek & 34 & 16,3 \\
\hline \multirow{3}{*}{ Tecrübe } & 1 yıldan az & 16 & 7,7 \\
& $1-3$ y yl & 22 & 10,6 \\
& $3-5$ yıl & 24 & 11,5 \\
& 5 yıldan fazla & 146 & 70,2 \\
\hline TOPLAM & & 208 & 100 \\
\hline \multicolumn{2}{c}{} & DEĞIŞKEN & & SD \\
\hline \multicolumn{2}{c}{} & Yaş & 35,52 & 9,04 \\
\hline
\end{tabular}

\subsection{Kapsam Geçerlilĭği}

Literatür incelemesi neticesinde oluşturulan taslak madde havuzu ile ilgili olarak sektör temsilcileri ve akademisyenlerden oluşan 10 kişilik bir grubun uzman görüşüne başvurulmuştur. Alınan görüş ve öneriler neticesinde ölçek maddeleri revize edilmiş ve taslak ölçek oluşturulmuştur.

\subsection{Yapı Geçerliliği}

Ölçeğin yapı geçerliliğinin test edilmesinde açımlayıcı faktör analizi kullanılmıştır. Faktör analizinin geçekleştirilebilmesi için öncelikle örneklem yeterliliği KMO katsayısı ve Bartlett küresellik testi ile incelenmiştir. Buna göre KMO katsayısı 0,842 ve Bartlett küresellik testi sonucu anlamlıdır $(\mathrm{p}<0.05)$. 


\section{D. Çavmak - E. Atalay - S. Söyler 11/3 (2019) 1897-1910}

Dolayısıyla örneklemin faktör analizi gerçekleştirilebilmesi için yeterli olduğu sonucuna ulaşılmıştır. Ardından faktör analizi gerçekleştirilmiştir.

Gerçekleştirilen faktör analizi soncunda ölçeğin öz değeri 1'den yüksek olan ve toplam varyansın \%55,36'sını açıklayan dört alt boyuttan oluştuğu tespit edilmiştir.

Madde faktör yükleri 0.40 'ın altında olan ve binişik madde olma özelliği gösteren 8 önerme ölçekten çıkarılarak faktör analizi tekrar gerçekleştirilmiştir. Ölçekten çıkartılan önermelerin, aile ve kariyer çatışması, çift kariyerlilik sorunu, kişi-iş uyumsuzluğu ve örgütsel baskı gibi bir dizi bileşeni yansıttığı gözlenmiştir. Ölçekten dışlanan önermeler, uygulamada yer aldıkları sıra numarası ile birlikte Tablo 2' de sunulmuştur.

Tablo 2. Ölçekten Dışlanan Önermeler

11.Kimi zaman ailevi konulardan dolayı iş süreçlerine odaklanamıyorum

12.Eşlerin ikisinin de çalışıyor olmasının evlilikte sıkıntılara yol açacağını düşünüyorum

13.Yüksek kariyer hedeflerine sahip olmanın iyi bir eş olmayı engelleyeceğini düşünüyorum

17.Aynı anda birden fazla alanda kariyer sahibi olmanın bir prestij unsuru olduğunu düşünüyorum

22.Bazen beraber çalıştı̆̆ım kişilerin benden tam olarak ne istediğini anlayamıyorum

24.İ̧̧imde başarılı olmam için yeteri kadar şans verilmediğini düşünüyorum

28.İş ile ilgili beklentilerim vardı fakat beklediğim bir ortamla karşılaşmadığımı düşünüyorum

30.Kariyerimde istediğim yere ulaşamadığım düşünüyorum

Gerçekleştirilen faktör analizinde düşük faktör yükü olan veya binişiklik gösteren herhangi bir önerme olmadığ1 saptanmıştır. Analize ilişkin döndürülmüş bileşen matrisi aşağıdaki gibidir(Önermeler uygulamadaki sıra numarası ile verilmiş, ölçeğin nihai hali çalışmanın ekinde sunulmuştur);

Tablo 3. Ölçeğin Boyutları ve Önermelerin Faktör Yükleri

\begin{tabular}{|c|c|c|c|c|}
\hline \multicolumn{5}{|c|}{ Döndürülmüş Bileşen Matrisi } \\
\hline & 1 & 2 & 3 & 4 \\
\hline s2 & ,808 & & & \\
\hline s3 & ,780 & & & \\
\hline s19 & 661 & & & \\
\hline s23 & 653 & & & \\
\hline $\mathrm{s} 20$ & 620 & & & \\
\hline s14 &, 579 & & & \\
\hline s10 &, 543 & & & \\
\hline s9 & ,533 & & & \\
\hline s1 & ,442 & & & \\
\hline s7 & & ,772 & & \\
\hline s6 & & ,735 & & \\
\hline s5 & & ,720 & & \\
\hline s4 & & ,674 & & \\
\hline s8 & & 627 & & \\
\hline s29 & &, 593 & & \\
\hline s21 & &, 517 & & \\
\hline s16 & & & 883 & \\
\hline s15 & & & 866 & \\
\hline s18 & & & ,785 & \\
\hline s27 & & & & ,770 \\
\hline s25 & & & & ,721 \\
\hline s26 & & & & ,637 \\
\hline s31 & & & &, 592 \\
\hline
\end{tabular}

\subsection{Doğrulayıcı Faktör Analizi Sonuçları}

Doğrulayıcı faktör analizi(DFA), çeşitli değişkenlerin oluşturmuş olduğu yapı ve bu yapının altında yatan ilişkileri ortaya çıkarması bakımından önemlidir. DFA, yeni bir ölçüm aracı geliştirilirken, aracın faktör 


\section{D. Çavmak - E. Atalay - S. Söyler 11/3 (2019) 1897-1910}

yapısını ortaya koymak ve kuramsal yapı ile modelin uyum gösterip göstermediğini test etmek üzere kullanılır. Birinci ve ikinci düzey olmak üzere iki tipte uygulanabilir (Gürbüz ve Şahin, 2017:340). Bu çalışmada, açımlayıcı faktör analizi ile oluşturulmuş olan yapı, birinci düzey DFA ile doğrulanmak üzere test edilmiştir.

Modele göre, önermelerin faktör yükleri ve hata varyansları aşağıdaki şekildeki gibidir.

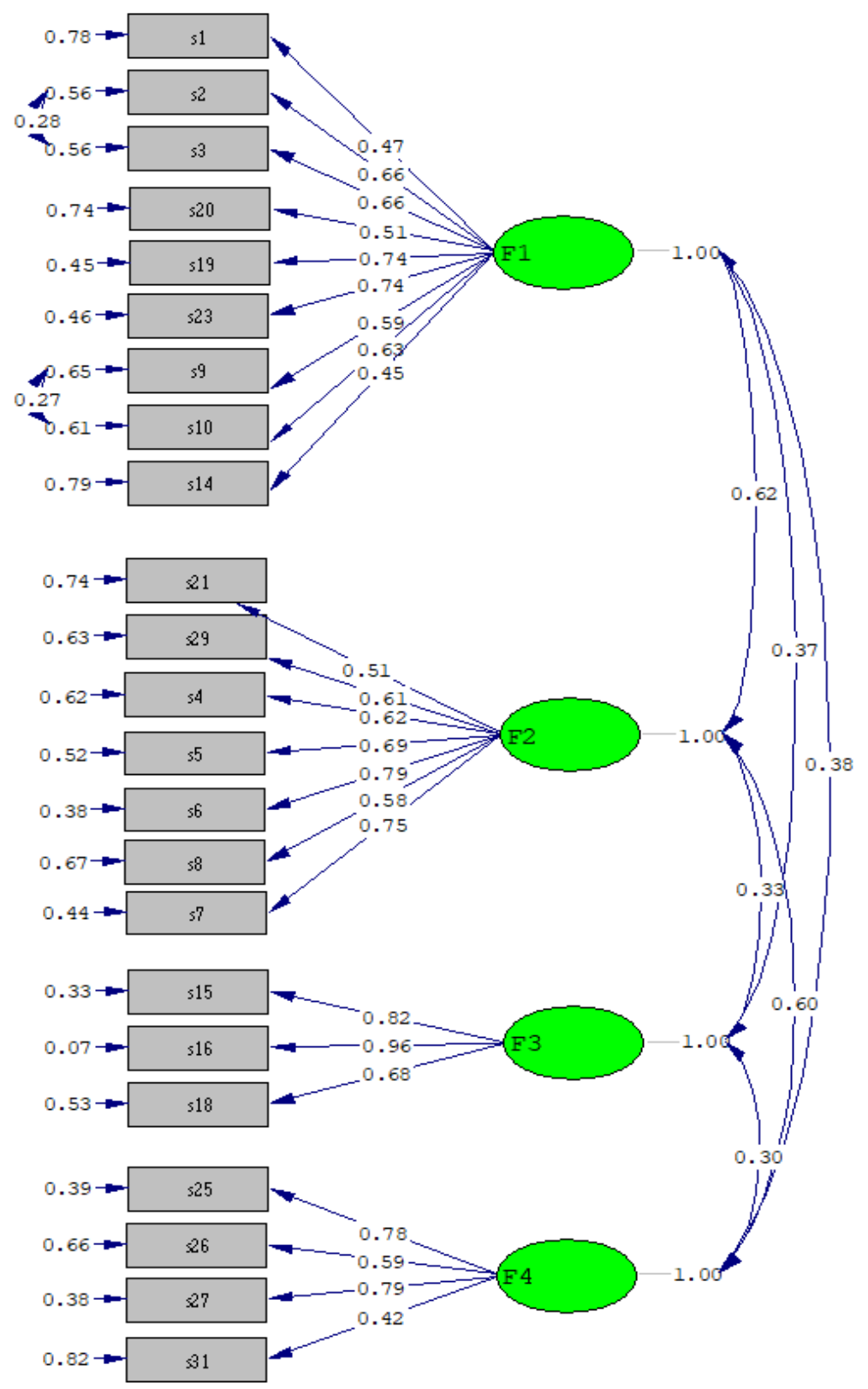

Şekil 1. DFA Sonuçları

Önermelerin örtük değişkenleri ile olan faktör yüklerinin 0.42-0.96 arasında değişiklik gösterdiği görülmüştür. Tüm parametrelerin $\mathrm{t}$ değerleri, anlamlılık düzeyini ifade eden 1.96 değerinden yüksektir. Dolayısı ile ilgili önermelerin, örtük değişkenler ile aralarındaki bağlantının anlamlı olduğu ifade edilebilir.

DFA'da modelin veri ile uyum gösterip göstermediğini tespit etmek için bazı ölçütlerin beklenen değerler arasında olması gerekmektedir. Bu ölçütler ve beklenen değerleri temel olarak aşağıdaki gibidir (Harrington 2009:51-52; Wang ve Wans 2012:17-22; Gürbüz ve Şahin, 2017:343). 
D. Çavmak - E. Atalay - S. Söyler 11/3 (2019) 1897-1910

Tablo 4. Kabul Edilebilir Uyum İndeks Değerleri

\begin{tabular}{|l|l|}
\hline \multicolumn{1}{|c|}{ Ölçüt } & \multicolumn{1}{|c|}{ Kabul Edilebilir Değer } \\
\hline Ki-Kare/Serbestlik Derecesi & $<3$ \\
\hline RMSEA(Tahmini Ortalama Karekök Hatası) & $<0.08$ \\
\hline SRMR(Standardize Ortalama Hataların Karekökü) & $<0.08$ \\
\hline CFI(Karşılaştırmalı Uyum İndeksi) & $>0.90$ \\
\hline GFI(Uyum İyiliği İndeksi) & $>0.85$ \\
\hline AGFI(Düzeltilmiş Uyum İyiliği İndeksi) & $>0.80$ \\
\hline IFI(Fazlalık Uyum İndeksi) & $>0.90$ \\
\hline
\end{tabular}

Ki-Kare/Serbestlik derecesi: model ile örneklemden elde edilen verinin uyumunu gösterir. RMSEA model ile örneklem kovaryansının uyumunu değerlendirmek için yararlanılan bir değerdir. Benzer olarak SRMR ölçütü, evrenin kovaryans matrisi ile örneklemin kovaryans matrisi arasındaki artık kovaryansları test etmektedir. GFI, örneklem büyüklüğünden etkilenmeden, model uyumunu test eden bir ölçütken, AGFI, bu ölçütün serbestlik derecesine göre ayarlanmış halidir. CFI, örneklem büyüklüğü ve serbestlik derecesini göz önünde bulundurarak, test edilen modelin temel model ile karşılaştırmasını yapar. IFI ise, modelin uyumunu, örneklem büyüklüğü ve karmaşıklık derecesine göre test eder (Gürbüz ve Şahin, 2017).

İlk aşamada modelin çalıştırılması sonrası uyum indeks değerlerinin, kabul edilebilir değer aralıklarının sınırında yer aldığı görülmüştür. Modelin birinci örtük değişken bünyesinde yer alan, 2-3 ve 9-10 numaralı önermelerine yönelik sunmuş olduğu modifikasyon önerileri gerçekleştirilmiş, ilgili önermelerin hata varyansları arasında kovaryans kurulmuştur. Sonrasında elde edilen değerlerin aşağıdaki tabloda görüleceği üzere, kabul edilebilir aralıklarda olduğu görülmüştür.

Tablo 5. Ölçeğin Uyum İndeks Değerleri

\begin{tabular}{|l|l|}
\hline Ölçüt & Elde Edilen Değer \\
\hline Ki-Kare & 426.04 \\
\hline Serbestlik Derecesi(df) & 222 \\
\hline Ki-Kare/df & 1,91 \\
\hline RMSEA & 0.067 \\
\hline SRMR & 0.071 \\
\hline CFI & 0.95 \\
\hline GFI & 0.85 \\
\hline AGFI & 0.81 \\
\hline IFI & 0.95 \\
\hline
\end{tabular}

\section{4. Ölçeğin Güvenilirliği}

Açımlayıcı ve doğrulayıcı faktör analizlerinin ardından ölçeğin güvenilirliği test edilmiştir. Ölçeğin ve alt boyutlarının zamana göre kararlılığını ölçmek amacıyla test-tekrar test yöntemi uygulanmıştır. Bu yöntem ölçeğin aynı gruba 3 hafta arayla tekrar uygulanması ve iki uygulama arasındaki korelasyonun incelenmesi şeklinde gerçekleştirilmektedir (Baş, 2013). Test ve tekrar test uygulamaları 50 katılımcı ile gerçekleştirilmiştir. İki uygulama sonuçları arasında yüksek düzeyde ve anlamlı bir ilişki olduğu tespit edilmiştir. İki uygulama arasında elde edilen ölçek ve alt boyutların korelasyonları Tablo 6' da özetlenmiştir. 


\section{D. Çavmak - E. Atalay - S. Söyler 11/3 (2019) 1897-1910}

Tablo 6. Test-Tekrar Test Sonuçları

\begin{tabular}{|l|c|c|c|c|}
\hline & Ilk Test & Son Test & r & P $^{*}$ \\
\hline Faktör 1 & $25,78 \pm 8,25$ & $37,41 \pm 11,26$ & 0,929 & 0,000 \\
\hline Faktör 2 & $16,48 \pm 4,67$ & $21,30 \pm 9,26$ & 0,966 & 0,000 \\
\hline Faktör 3 & $8,32 \pm 3,75$ & $11,70 \pm 5,53$ & 0,915 & 0,000 \\
\hline Faktör 4 & $8,08 \pm 3,56$ & $14,14 \pm 5,67$ & 0,875 & 0,000 \\
\hline Genel Ölçek & $58,66 \pm 14,51$ & $84,58 \pm 23,19$ & 0,945 & 0,000 \\
\hline
\end{tabular}

*Pearson korelasyon analizi uygulanmıştır.

Genel ölçeğin iç tutarlılığını ifade eden Cronbach's alpha katsayısı 0,893 olarak bulunmuştur. Bu değer ölçeğin güvenilir olduğunu ifade etmektedir. Benzer şekilde ölçeğe ilişkin alt boyutlar da ayrı ayrı değerlendirildiğinde iç tutarlılık katsayılarının 0.70 'ten büyük olduğu ve alt boyutların da güvenilir olduğu tespit edilmiştir. Ölçek genelinin ve alt boyutlarının iç tutarlılık katsayıları Tablo 7' de özetlenmiştir.

Tablo 7. İç Tutarlılık Analizi Sonuçları

\begin{tabular}{|c|c|}
\hline Boyutlar & Cronbach Alpha \\
\hline F1 & 0,849 \\
\hline F2 & 0,832 \\
\hline F3 & 0,857 \\
\hline F4 & 0,735 \\
\hline Genel & 0,893 \\
\hline
\end{tabular}

\subsection{Boyutların Adlandırılması}

Analiz sonucu oluşan "Hemşirelikte Kariyer Sorunları Ölçeği”nin alt boyutları, içerdikleri önermeler çerçevesinde aşağıdaki gibi adlandırılmıştır.

Tablo 8. Boyutlar ve Adlandirma

\begin{tabular}{|l|l|}
\hline F1 & Stres ve Tükenme \\
\hline F2 & Organizasyonel Baskı ve Mesleki Uyumsuzluk \\
\hline F3 & Çift Kariyerlilik Sorunu \\
\hline F4 & Kariyerde Cinsiyet Kaynaklı Sorunlar \\
\hline
\end{tabular}

\section{Tartışma ve Sonuç}

Bu çalışmada hemşirelerin kariyerlerinde yaşadıkları problemlere yönelik bir ölçek geliştirilmiştir. Araştırma 208 hemşire ile gerçekleştirilmiş, ayrıca 50 hemşireye üç hafta ara ile test-tekrar test uygulanmıştır. Ölçeğin geçerlilik ve güvenilirliğine yönelik analizler gerçekleştirilmiştir. Ölçeğe ilişkin geçerlilik hem yapı hem de kapsam yönünden değerlendirilmiştir. Faktör analizleri neticesinde 31 maddeden oluşturulan taslak ölçekten 8 madde çıkarılmış ve ölçek 23 maddelik nihai formatına ulaşmıştır. Ayrıca hem genel ölçeğin hem de ölçek alt boyutlarının içsel tutarlılığını gösteren Cronbachs' alpha katsayısının 0.70 'ten yüksek olduğu tespit edilmiş olup bu katsayı ölçeğin güvenilir olduğuna işaret etmektedir. Ölçeğin zamana göre kararlılığının ölçülmesinde kullanılan test-tekrar test sonucunda ise test puanları ile tekrar test puanları arasında yüksek bir korelasyon olduğu tespit edilmiştir.

Geçerlilik ve güvenilirliği test edilen ölçek, dört alt boyuttan oluşan 7'li likert tipi bir ölçektir. Ölçeğin alt boyutları; 9 maddeden oluşan stres ve tükenme, 7 maddeden oluşan organizasyonel baskı ve mesleki uyumsuzluk, 3 maddeden oluşan çift kariyerlilik sorunu ve 4 maddeden oluşan kariyerde cinsiyet kaynaklı sorunlar şeklindedir. Ölçekten alınabilecek minimum puan 23 ve maksimum puan 161'dir. Artan puanlar hemşirelerin ilgili boyutu bir kariyer sorunu olarak algıladığını/deneyimlediğini ifade etmektedir.

Literatürde kariyer sorunları ile ilgili çok sayıda ölçek yer almaktadır. Ancak bu ölçekler ayrı ayrı değerlendirilmiş olup bir meslek grubuna yönelik bütüncül bir ölçme aracı olma özelliği göstermemektedirler. Örneğin literatürde yer alan bir iş tatmini ölçeği sadece iş tatminini ölçmekte, diğer faktörleri göz ardı etmektedir. Ayrıca literatürde yer alan ölçekler farklı alanlardaki gruplara uygulanabilse de, sağlık alanının 


\section{D. Çavmak - E. Atalay - S. Söyler 11/3 (2019) 1897-1910}

kendisine has özellikleri ve karakteristikleri nedeniyle hemşirelere uygulanabilirliği kısıtlıdır. Bu bağlamda, bu araştırmada içerisinde bulundukları çalışma ortamı, yaptıkları işin temel karakteristikleri ve sahip oldukları demografik özellikler nedeniyle özellikli bir grup olan hemşirelerin kariyer sorunlarını bütüncül bir bakış açısıyla ölçebilecek bir ölçme aracı geliştirilmiştir.

\section{Kaynaklar}

Acar, A. C. (1994). “İki Kariyerli Aileler ve İşletmeler”, Yönetim Dergisi, 5(17): 21-29.

Akbal Ergün, Y., Batlaş, Z., Özer, Y. (2001). “Yoğun Bakımda Çalışan Hemşirelerin Stres Düzeyleri ve Stresin Hemşireler Üzerindeki Etkileri", Yoğun Bakım Hemşireler Derneği Yayın Organı, Cilt:5, Sayı.2, s:7079 .

Aktaş, K. (2015). “Genel Anlamda Kariyer ve Kariyer Sorunları”, Sosyal Araştırmalar ve Davranış Bilimleri Dergisi, 1: 26-36.

Aydemir, N. (1995). “2000’li Yıllara Doğru Özel Sektör İmalat Sanayiinde İnsan Kaynakları Yönetimi ve Kariyer Arayışları", İstanbul: Simge Ofis Matbaacılık.

Aytaç, S. (2005). "Çalışma Yaşamında Kariyer: Yönetimi, Planlaması, Gelişimi ve Sorunları", Bursa: Ezgi Kitapevi.

Baltaş, A. ve Baltaş, Z. (2008). “Stres ve Başa Çıkma Yolları”, İstanbul: Remzi Kitabevi.

Baş, Türker (2013). “Anket Nasıl Hazırlanır? Anket Nasıl Uygulanır? Anket Nasıl Değerlendirilir?”, Ankara: Seçkin Yayıncilık.

Bektemür, G., Demiray, S. ve Özdemir Ürkmez, D. (2016). “Hemşirelerin Kariyer Planlaması: Bir Eğitim ve Araştırma Hastanesi Örneği", Okmeydanı Tıp Dergisi, 32(1): 7-13.

Bombuwela P. M. Ve Chamaru, D. A. (2013). "Effects Of Glass Ceiling On Women Career Development in Private Sector Organizations Case Of Sri Lanka", Journal of Competitiveness, 5(2): 3-19.

Budak, G. (2008). “Yetkinliğe Dayalı İnsan Kaynakları Yönetimi”, İzmir: Barış Yayınları.

Cam, E. (2004). "Çalışma Yaşamında Stres ve Kamu Kesiminde Kadın Çalışanlar”, Uluslararası İnsan Bilimleri Dergisi, 1(1): 1-10.

Can, R., Hisar, K.M. (2019). Hemşirelerin Profesyonellik Davranışları ve Tükenmişlik Düzeyleri. Hacettepe Üniversitesi Hemşirelik Fakültesi Dergisi, 6(1):1-9.

Çalışkan, A., Pekkan, N.U. (2019). Sağlık Sektörü Çalışanlarında Tükenmişlik Duygusunun İşten Ayrılma Niyetine Etkisi:Kişi-Örgüt Uyumunun Aracılık Rolü. 10(2):469-481.

Çatak, T. ve Bahçecik, N. (2015). “Hemşirelerin iş Yaşamı Kalitesi ve Etkileyen Faktörlerin Belirlenmesi", Clinical and Experimental Health Sciences, 5(2): 85-95.

Demirel, E.T. (2017). “İnsan Kaynakları Yönetiminde Güncel Yaklaşımlar”, İstanbul: Beta Yayınevi.

Ergüney S, Tan M, Sivrikaya S (2001). "Hemşirelerin karşılaştıkları mesleki riskleri”, Atatürk Üniversitesi Hemşirelik Yüksekokulu Dergisi 4 (1): 63-72.

Ergüney S., Tan M., Sivrikaya S.\& Erdem N. (2001). "Hemşirelerin Karşılaştıkları Mesleki Riskler",Atatürk Üniversitesi Hemşirelik Yüksekokulu Dergisi, 4:1, s.63-73.

Flippo, E. B. (1984). "Personnel Management", Singapoure, McGraw-Hill, International EditionsManagement Series.

Greenhaus, J.H. ve Beutel, N. J. (1985). "Sources of Conflict between Work and Family Roles", Academy of Management Rewiew, 10(1): 76-88.

Gürbüz, S. (2017). “İnsan Kaynakları Yönetimi”, Ankara: Seçkin Yayıncılık. 


\section{D. Çavmak - E. Atalay - S. Söyler 11/3 (2019) 1897-1910}

Gürbüz, S. Ve Şahin, F. (2017). “Sosyal Bilimlerde Araştırma Yöntemleri Felsefe-Yönetim-Analiz”, Ankara: Seçkin Yayınları.

Harrington (2009). “Confirmator Factor Analysis”, New York, Oxford University Press.

Karaca, A. (2007). “Kadın Yöneticilerde Kariyer Engelleri: Cam Tavan Sendromu Üzerine Uygulamalı Bir Araştırma", Yüksek Lisans Tezi, Selçuk Üniversitesi, Sosyal Bilimler Enstitüsü, Konya.

Karaca, Ö. (2019). “Hemşirelerin Kariyer Gelişimleri Ve Yönetimleri Sırasında Karşılaştıkları Cinsiyetçi Yaklaşımlar: Nitel Bir Çalışma", Yüksek Lisans Tezi, Marmara Üniversitesi, Sağlık Bilimleri Enstitüsü, İstanbul.

Karadoğan, E. (2009). “Mesleksel Gelişimi Hedefleyen Eşler”, Ankara Üniversitesi SBF Dergisi, 64(4): 137-152.

Karahan, A. ve Bener, Ö. (2005). “Bolu Sosyal Sigortalar Kurumu Hastanesinde Çalışan Evli Hemşirelerin Ev Ortamında Yaşadıkları Sorunlar", Sosyal Politika Çalışmaları Dergisi, 8(8).

Karahan, A., Gürpınar, K. ve Özyürek, P. (2007). "Hizmet Sektöründeki İşletmelerin Örgüt İçi Stres Kaynakları: Afyon İl Merkezindeki Hastanelerde Çalışan Cerrahi Hemşirelerinin Stres Kaynaklarının Belirlenmesi", Ekonomik ve Sosyal Araştırmalar Dergisi, 3 (1): 27-44.

Karakuş, H. (2011). "Hemşirelerin İş Tatmin Düzeyleri: Sivas İli Örneği”, Dicle Üniversitesi Sosyal Bilimler Enstitüsü Dergisi, 3(6): 46-57.

Kırmızıgül, B. (2017). “İnsan Kaynakları Yönetiminde Güncel Yaklaşımlar”, İstanbul: Beta Yayınevi.

Kimmel, J., Conway, K.S. (2001). "Who Moonlight And Why? Evidence From The SIPP”, Industrial Relationd, January, 40(1), pp. 89-120.

Koç, S., Bardak, A. ve Yılmaz, K. (2014). “Hemşirelik Son Sınıf Öğrencilerinin İş Yerinden Beklentilerinin Belirlenmesi", Koç Üniversitesi Hemşirelikte Eğitim ve Araştırma Dergisi (HEAD), 11(3): 43-50.

Kopelman, R. E., Greenhaus, J. H. ve Connolly, T.F. (1983). “A Model of Work, Family, and Interrole Conflict: A Construct Validation Study", Organizational Behavior and Human Decision Performance, 32(2): 198215.

Leymann, H. (1996). "The Content and Development of Mobbing at Work", European Journal of Work and Organizational Psychology, 5(2): 165-184.

Marangoz, H. (2019). "Toplumsal cinsiyete dayalı işbölümü ve işyerinde ayrımcılık: Kadın hemşireler örneği", Yüksek Lisans Tezi, Tekirdağ Namık Kemal Üniversitesi, Sosyal Bilimler Enstitüsü, Tekirdağ.

Maslach, C. ve Jackson, S. E. (1981). "The Measurement of Experienced Burnout”, Journal of Occupational Behavior, 2: 99-113.

Maslach, C. ve Leiter, M. P. (1997). “The Truth About Burnout: How Organizations Cause Personal Stress and What To Do About It", San Francisco, Jossey-Bass.

Mutlu, A. (2010). "Hemşirelerin Kariyer Planlamasına İlişkin Görüşlerinin Belirlenmesi”, Yüksek Lisans Tezi, Marmara Üniversitesi, Sağlık Bilimleri Enstitüsü, İstanbul.

Okakın, N. (2009). “Çalışma Yaşamında İnsan Kaynakları Yönetimi” (2. Baskı), İstanbul: Beta Yayınları.

Özdevecioğlu, M. (2003). “Algılanan Örgütsel Destek ile Örgütsel Bağlllık Arasındaki İlişkilerin Belirlenmesine Yönelik Bir Araştırma", Dokuz Eylül Üniversitesi İ̈BF Dergisi, 18(2): 113-130.

Özen, M., Yüceler, A. (2019). Sağlık Çalışanlarında Duygusal Emek, Tükenmişlik ve İş Tatmini İlişkisinin İncelenmesi: Konya İlinde Bir Uygulama. Selçuk Üniversitesi Sosyal Bilimler Enstitüsü Dergisi, 41:194209.

Öztürk, H., Kurt, Ş., Mersinlioğlu Serin, G., Bayrak, B., Balık, T. ve Demirbağ, B. C. (2016). “Hastanelerde İşe Yeni Başlayan Hemşirelerin Sorunları", Acıbadem Üniversitesi Sağlık Bilimleri Dergisi, 4: 189-201.

Öztürk, H., Kurt, Ş., Mersinlioğlu Serin, G., Bayrak, B., Balık, T., \& Demirbağ, B. C. (2016). Hastanelerde İşe Yeni Başlayan Hemşirelerin Sorunları 
D. Çavmak - E. Atalay - S. Söyler 11/3 (2019) 1897-1910

Özünlü, D. (2013). “Cam tavan sendromunun örgütsel bağlllık üzerindeki etkisini ölçmeye yönelik bir araştırma", Yüksek Lisans Tezi, Dumlupınar Üniversitesi, Sosyal Bilimler Enstitüsü, Kütahya.

Rapoport, R. ve Rapoport, R.N. (1971). "Further Considerations on the Dual Career Family", Human Relatıons, 24(6): 519-533.

Seçkin, Ş.N. (2017). “İnsan Kaynakları Yönetiminde Güncel Yaklaşımlar”, İstanbul: Beta Yayınları.

Shirom, A. (1989). "Burnout in Work Organizations" Cooper ve Robertson (eds.) International Review Of Industrial and Organizational Psychology, Oxford, John Wiley \& Sons.

Smith, P., Crittenden, N. \& Caputi, P., (2012). "Measuring women's beliefs about glass ceilings: Development of the career pathways survey", Gender in Management, 27 (2), pp. 68-80.

Şimşek, M. Ş. ve Öge, H. S. (2014). “İnsan Kaynakları Yönetimi”, Konya: Eğitim Yayınevi.

Şirin, A., Öztürk, R., Bezci, G., Çakar, G. ve Çoban, A. (2008). “Hemşirelik Öğrencilerinin Meslek Seçimi ve Mesleği Uygulamaya Yönelik Görüşleri”, Dirim Tip Gazetesi, 83(1): 69-75.

Tınaz, P. (2008). “İşyerlerinde Psikolojik Taciz (Mobbing)”, (2.Baskı), İstanbul: Beta Yayınları.

Topuz, A. (2006). “Hemşirelerde Rol Çatışması ve Rol Belirsizliği, İş Stresi ve Aralarındaki İlişkinin Belirlenmesi", Yüksek Lisans Tezi, Cumhuriyet Üniversitesi Sağlık Bilimleri Enstitüsü, Sivas.

Wang, J. ve Wang, X. (2012). "Structural Equation Modeling: Applications Using, Mplus", Sussex, John Wiley\&Sons.

Wirth, L. (2001). "Breaking Throughbthe Glass Ceiling Women İn Management", Genevia, International Labour Ofice.

YILDIRIMALP, S., Mert, Ö. N. E. R., \& Yenihan, B. (2014). Hemşirelerin İş-Aile Çatışması ve Yaşam Tatmini Düzeyleri: Demografik Özellikler Açısından Bir Değerlendirme. Siyaset, Ekonomi ve Yönetim Araştırmaları Dergisi, 2(3).

Yüksel, İ. (2005). "İş-Aile Çalışmasının Kariyer Tatmini, İş Tatmini ve İş Davranışları ile İlişkisi”, Atatürk Üniversitesi İktisadi ve İdari Bilimler Dergisi, 19(2): 301-314.

Mrayyan, M.T. (2007). Nursing Practice Problems in Private Hospitals in Jordan: Student's Perspectives. Nurse Education in Practice Journal. 7:82-87.

Cox, T., Griffithis, A., Cox, S. (1996). Work-related stress in Nursing: Controlling The Risk to Health. International Labor Office Publication, Geneva. 


\section{Ek- Nihai Ölçek}

\begin{tabular}{|c|c|c|c|c|c|c|c|}
\hline \multirow{2}{*}{$\begin{array}{l}\text { Önermeler } \\
\text { F1 (Stres ve Tükenme) }\end{array}$} & \multicolumn{7}{|c|}{ Kesinlikle Katılmıyorum I------------I Kesinlikle Katılıyorum } \\
\hline & & & & & & & \\
\hline $\begin{array}{l}\text { 1. Hizmet sunduğum kişilere karşı duyarsız ve ilgisiz hale } \\
\text { gelmeye başladığımı hissediyorum }\end{array}$ & 1 & 2 & 3 & 4 & 5 & 6 & 7 \\
\hline $\begin{array}{l}\text { 2.Sabah yeni bir iş gününe başlarken yorgun ve bezgin } \\
\text { hissediyorum }\end{array}$ & 1 & 2 & 3 & 4 & 5 & 6 & 7 \\
\hline 3.Çok fazla çalıştığımı ve yıldığımı hissediyorum & 1 & 2 & 3 & 4 & 5 & 6 & 7 \\
\hline $\begin{array}{l}\text { 4.Aileme vakit ayıramadığım için işimden ayrılmayı } \\
\text { düşündüğüm oluyor }\end{array}$ & 1 & 2 & 3 & 4 & 5 & 6 & 7 \\
\hline $\begin{array}{l}\text { 5.Gece nöbetlerinin aile yaşamında sıkıntılara sebep } \\
\text { olacağını düşünüyorum }\end{array}$ & 1 & 2 & 3 & 4 & 5 & 6 & 7 \\
\hline $\begin{array}{l}\text { 6..İ̧̧imle ilgili konular iş dışındaki saatlerde de zihnimi } \\
\text { meşgul eder }\end{array}$ & 1 & 2 & 3 & 4 & 5 & 6 & 7 \\
\hline $\begin{array}{l}\text { 7.İ̧ yüküm çok fazla olduğu için işimi olabileceğinden } \\
\text { daha düşük kalite ile yapmak zorunda kalıyorum }\end{array}$ & 1 & 2 & 3 & 4 & 5 & 6 & 7 \\
\hline 8.Aile yaşamım ile iş yaşamım birbiri ile çakışıyor & 1 & 2 & 3 & 4 & 5 & 6 & 7 \\
\hline $\begin{array}{l}\text { 9.Normal bir iş gününde bitirilemeyecek kadar ağır bir iş } \\
\text { yüküm olduğunu düşünüyorum }\end{array}$ & 1 & 2 & 3 & 4 & 5 & 6 & 7 \\
\hline \multicolumn{8}{|l|}{ F2 (Organizasyonel Baskı ve Mesleki Uyumsuzluk } \\
\hline $\begin{array}{l}\text { 10. İş ortamında ben yokmuşum gibi davranıldığını } \\
\text { hissediyorum. }\end{array}$ & 1 & 2 & 3 & 4 & 5 & 6 & 7 \\
\hline $\begin{array}{l}\text { 11.Genellikle basit ve uzmanlık gerektirmeyen işlerin bana } \\
\text { verildiğini düşünüyorum. }\end{array}$ & 1 & 2 & 3 & 4 & 5 & 6 & 7 \\
\hline $\begin{array}{l}\text { 12.Kariyer gelişimimin kasti olarak engellenmeye } \\
\text { çalışıldığını düşünüyorum }\end{array}$ & 1 & 2 & 3 & 4 & 5 & 6 & 7 \\
\hline $\begin{array}{l}\text { 13.İş ortamında azarlanmam için bahane arandığını } \\
\text { düşünüyorum }\end{array}$ & 1 & 2 & 3 & 4 & 5 & 6 & 7 \\
\hline 14.Sözlü veya fiziki tacize maruz kalıyorum & 1 & 2 & 3 & 4 & 5 & 6 & 7 \\
\hline $\begin{array}{l}\text { 15.Sorumluluklarımı yerine getirmek için yeterli yetkiye } \\
\text { sahip olmadığımı düşünüyorum }\end{array}$ & 1 & 2 & 3 & 4 & 5 & 6 & 7 \\
\hline $\begin{array}{l}\text { 16.Aldığım eğitim, tutumum ve kişiliğimin çalıştığım } \\
\text { kurumla uyuşmadığını düşünüyorum }\end{array}$ & 1 & 2 & 3 & 4 & 5 & 6 & 7 \\
\hline \multicolumn{8}{|l|}{ F3 (Çift Kariyerlilik Sorunu) } \\
\hline $\begin{array}{l}\text { 17.Birden fazla uzmanlık alanına sahip olmanın bir alana } \\
\text { odaklanmayı zorlaştıracağını düşünüyorum }\end{array}$ & 1 & 2 & 3 & 4 & 5 & 6 & 7 \\
\hline $\begin{array}{l}\text { 18.Birden fazla uzmanlık alanına sahip olmanın kariyerde } \\
\text { başarısızlığa yol açacağını düşünüyorum }\end{array}$ & 1 & 2 & 3 & 4 & 5 & 6 & 7 \\
\hline $\begin{array}{l}\text { 19.Aynı anda birden fazla alanda kariyer sahibi olmanın } \\
\text { uzmanlaşmayı engelleyeceğini düşünüyorum }\end{array}$ & 1 & 2 & 3 & 4 & 5 & 6 & 7 \\
\hline \multicolumn{8}{|l|}{ F4(Kariyerde Cinsiyet Kaynaklı Sorunlar) } \\
\hline $\begin{array}{l}\text { 20.Üst düzey bir pozisyonda görev almanın erkeklere } \\
\text { k1yasla daha zor olacağını düşünüyorum }\end{array}$ & 1 & 2 & 3 & 4 & 5 & 6 & 7 \\
\hline $\begin{array}{l}\text { 21.Üst düzey pozisyonlara gelmek için çok fazla taviz } \\
\text { vermem gerektiğini düşünüyorum }\end{array}$ & 1 & 2 & 3 & 4 & 5 & 6 & 7 \\
\hline $\begin{array}{l}\text { 22.Cinsiyetin üst düzey bir pozisyon için belirleyici bir } \\
\text { faktör olduğunu düşünüyorum }\end{array}$ & 1 & 2 & 3 & 4 & 5 & 6 & 7 \\
\hline $\begin{array}{l}\text { 23.Değişen teknolojik gelişmelere adapte olamayacağımı } \\
\text { düşünüyorum }\end{array}$ & 1 & 2 & 3 & 4 & 5 & 6 & 7 \\
\hline
\end{tabular}

